\title{
Researching Protest Literacies: Literacy as Protest in the Favelas of Rio de Janeiro
}

\author{
Jamie D. I. Duncan \\ Routledge, 2021, pp. 251
}

\section{Reviewed by Catherine Compton-Lilly University of South Carolina}

1

The propensity to protest is a global phenomenon. The Arab Spring, the

international Occupy movement, the

Women's March following Trump's election, the Me Too movement, protests in Hong Kong, rallies challenging Brexit, and Black Lives Matter share a commitment to social change that is grounded in the experiences of people. The most obvious literacy practices of protest are the signs carried by protesters; however, Jamie Duncan's book moves beyond what is readily apparent to explore literacy's layered roles in "mobilizing, performing, and disseminating of

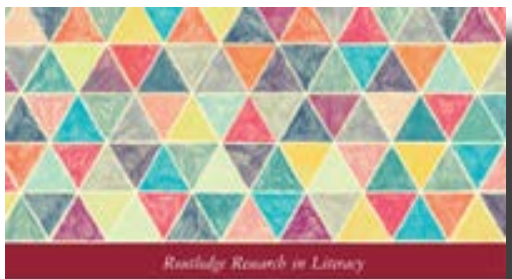

RESEARCHING PROTEST LITERACIES

UTIERACY AS PROTEST IN THE FAVELAS OF RIO DE JANEIRO

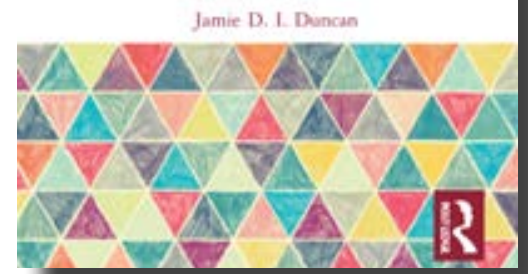
demonstrations and interrelated activities" (3).

As Duncan argues across the book, protest is a temporal process that involves trajectories of actions, texts, and people who mobilize to enact and simultaneously construct trajectories. In the book, protest literacies and associated texts are both parts of processes and moments-semiotic events that contribute to meaning construction. Through locating his research within the Maré favela or neighborhood in Rio de Janeiro, Duncan explores how space affects people's experiences and the mechanisms that define equity and inequity in people's lives. In America, there's the slum, the ghetto, and the other side of the tracks; in Brazil there is the favela. Using the fave$l a$ as a place frame, Duncan demonstrates how time, space, and people come together to create a context for making meaning.

It is this longitudinal construction of meaning that fascinates me about Duncan's book. Literacy scholars, for example Louise M. Rosenblatt, tend to agree that meanings are constructed in transaction with texts. While Duncan's volume may seem to be about protest in one community, within a city, in a country, on the other side of the world, it examines universal flows that entail emergence, construction, and circulation of meanings through trajectories involving entwined literacy practices. Trajectories of meaning making are continual and ubiquitous; they are always happening around us. What is unique about this analysis of protest literacies is that Duncan has made the emergence of meaning visible and visceral. By attending to observable events-in this case a series of protests that can be conceived of as having a discern- 
able beginning and ending-we witness the emergence of making meaning; observe how meanings loop in, through and across texts; and consider how sense-making translates into personal and collective action.

Through the example of protests in Maré, Duncan makes the theoretical concrete as local residents protest police violence and the gentrification of their community to accommodate the hosting of the FIFA World Cup. Duncan further explores the following five examples of protest literacies in the book: "campaigning literacies, memorial literacies, media-activist literacies, arts-activist literacies, and demonstration literacies" (11). Each chapter focuses on one of these literacies, while making connections and noting intersections across these forms. In each chapter, readers learn about a distinct but embedded layer of literacy practices that contributes to meaning making and its evolution. In chapter one, readers are introduced to Duncan's personal trajectory as they accompany him into the favelas of Rio de Janeiro. Chapter two provides a historical review of the Maré community and the Brazilian context. Duncan's historical ethnography is discussed and described in chapter three. Herein, readers learn about Duncan's role as a participant observer, his phases of data collection, and his "guided gaze" as residents discuss, display, reveal, and protect their worlds (55).

The next section of the book explores the literacy practices that Duncan tracked over time. Chapter four focuses on trajectories of symbols and how they are operationalized by protestors to become and serve as symbols of protest. Duncan focuses on the "Skull," which is a type of armored car that is routinely used by military police to control protests in Brazil. As Duncan aptly illustrates, this vehicle and images invoked by its name become a representation of excessive force, death, and a symbol of protest. Not only so does the word 'Skull' and associated symbols appear in political texts and news reports, but it is taken up and deployed in human rights campaigns, protest signs, and community documents. Thus, Duncan tracks the symbol and its associated meanings across time and within and beyond the community as the "Skull" assumes meanings, becoming a tool for collective resistance.

As described in chapter five, memorial literacies and their trajectories are deeply grounded in the community. As Duncan argues, memorialization of people who have been lost to the struggle serve as powerful symbols. In Maré, remembrances of an eight-year-old boy named Matheus-who was killed by military police-serves as a reminder of injustice. Agency is clearly local with commemorative protests occurring outside of the family's home and involving his mother, grandmother, and siblings. The associated texts are unpretentious and often handmade; articles cut from newspapers, photos, notes, placards, and print-outs are displayed and carried. A testament to this memorialization of individuals is the repetition and recurrence of symbols-Matheus' name and image-and the repetition and recurrence of similar atrocities. Acts of memorialization and their associated literacy practices and texts operate in chains of events and through literacy practices that are accompanied by speeches, song, and testimonials that further contribute to assemblages of protest. While located in the present, these assemblages, reference past acts and indexically reference collective and cultural memories that define communities. Thus, remembrance and 
protest come together through the memorialization of individuals whose stories represent collective loss and struggle.

Chapter six explores a third form of literacy involved in protest: media-activist literacy. In this instantiation of protest, residents of Maré collaborate with media agencies and journalists to raise awareness and mobilize action in response to local issues. These efforts involve the "production and publication of written 'articles', often accompanied with illustrational or photographic accompaniments" that include the accounts of local residents and increasingly involve social and online media (Duncan 107). The texts not only reach beyond local communities-sometimes involving international human rights issues-but also explicitly connect particular incidents (e.g., the death of an eight-year-old child) to contemporaneous policies (e.g., changes on community policing policies) and historical events (e.g., earlier protests, prior deaths). This linking of past and present presents a trajectory of textuality and protest that not only references retrospective patterns, but also references future dangers and possibilities, highlighting the need for social change. Thus, media-activist literacy plays a significant role in expanding the relevance of events through connections with the past, the present moment and possibilities for the future, while connecting events in Maré to global protests.

In chapter seven, resistance to the World Cup and policing practices come together and their emergence becomes a movement. This movement's consolidation and crystallization emerges through graffiti and street art, protest signs, and symbols that contribute to a "creative and transgressive political and semiotic landscape" (Duncan 141). The circulation of symbols of resistance extend beyond the favela through online spaces and begin to appear in more affluent communities.

In chapter eight, we join the protest. Focusing on a particular event in June 2014, readers witness the generation of texts with the protest spaces. People gather and are provided with resources-stencils, cardboard, markers, and spray paint-that they use to create physical texts of protest. Documented by local media, mass media, and participants' cell phones, the group moves along the parade route. Along the way, texts are created, negotiated, and confiscated. Following the event, images of this protest become symbolically useful for publicizing future civil actions.

In chapter nine, Duncan invites us to witness the cooling off of protest activities. In this final chapter, the people of Maré successfully prevent the eviction of a popular community museum and community center as protestors take up, operationalize, and invoke texts and practices from past protests. In the wake of this eviction victory, military police occupation ends in Maré, which diminishes a central concern of the protesters. In the months that follow, an economic recession, corruption scandals, a presidential impeachment, and an increase in far-right political influences diminish the energy surrounding local protest. As energy wanes, the movement is transformed "from a powerful anticipatory trajectory into the personal memories of people involved and the cultural memory of social movements of protest" (Duncan 215).

Given the abundance of protest movements around the world, documenting the emergence and trajectory of a sequence of protest-particularly one that resulted in discernable gains-is a valuable contribution to literacy educators. While scholars 
such as Norman Fairclough have discussed the circulation of texts for decades, there are few clear examples of textual tracking. Duncan, has brilliantly provided an exemplar in this book. With this in mind, I offer that a critical contribution of this book is that it extends beyond protest to the tracking of texts and meanings across time and space. Certainly understandings related to protest literacies are near and dear to the hearts of critical literacy educators, but there are many more textual flows and accompanying semiotic trajectories that could be explored by educators. What would it mean to track the emergence and use of texts that describe students (i.e., "struggling," "gifted," "traumatized"), literacy programs (i.e., "scripted," "multi-sensory," "scientifically-based"), or theoretical constructs (i.e., "anti-racist," "new materialist," "cosmopolitanism")? What might be questioned, revealed, recognized, and accomplished by applying ethnographic methods to track textual trajectories across literacy scholarship, within and across communities, and in relation to various educational institutions? These questions point to the significance of Duncan's book and its contribution to the field.

\section{Works Cited}

Fairclough, Norman. Analysing Discourse: Textual Analysis for Social Research. Psychology Press, 2003.

Rosenblatt, Louise M. “The Transactional Theory: Against Dualisms. College English, vol. 55, no. 4, 1993, pp. 377-86. 